\title{
Preparing Guest Room for Tourists in Sidetapa Village, Buleleng, Bali
}

\author{
Ni Made Ary Widiastini ${ }^{1, *}$ Putu Indah Rahmawati ${ }^{1}$ Made Aristia Prayudi $^{2}$ I Gede \\ Rasben Dantes ${ }^{3}$ Putu Andi Wirasetia ${ }^{4}$
}

\author{
${ }^{1}$ Department of Management, Universitas Pendidikan Ganesha, Singaraja, Indonesia \\ ${ }^{2}$ Department of Economic and Accounting, Universitas Pendidikan Ganesha, Singaraja, Indonesia \\ ${ }^{3}$ Department of Computer Science, Universitas Pendidikan Ganesha, Singaraja, Indonesia \\ ${ }^{4}$ Postgraduate Programme in Management, Universitas Pendidikan Ganesha, Singaraja, Indonesia \\ *Corresponding author. Email ary.widiastini@undiksha.ac.id
}

\begin{abstract}
The availability of clean rooms accompanied by adequate equipment is a necessity for every tourist destination, including in tourist villages. Understanding the needs of tourists for the availability of these rooms, in the partner village assistance program, two unused rooms are assisted for the repair process and the preparation of all the equipment. The selection of rooms that are prepared to be guest rooms for tourists is based on their contribution to the community, namely the bamboo craft centre which has a major contribution to the empowerment of craft women groups and the foreign language learning centre that provides free training with the concept of caring for the environment to school children. The two places are also tourist destinations. Most tourists have the motivation of studying local culture and as volunteer, namely teaching foreign languages while traveling. It is hoped that the presence of two rooms in the two centres can contribute economically to the sustainability of the management of the tourist village.
\end{abstract}

Keywords: Preparing, Room, Sidetapa village, Tourist.

\section{INTRODUCTION}

The development of tourist villages in its implementation requires the support of various roles, both at the central, regional government levels, to all elements in the village. The government, in this case the Ministry of Tourism and the Ministry of Villages, Development of Disadvantaged Regions and Transmigration, has collaborated in a memorandum of understanding number 10/M-DPDTT/KB/XII/2016 concerning Tourism Village Development, which was continued through the implementation of the Cooperation Agreement (PKS) in April 2017. The purpose of this Cooperation Agreement is to develop Tourism Villages through the development and empowerment of rural communities in order to increase the number of domestic and foreign tourist visits and efforts to drive the economy to improve the welfare of rural communities.

Sidetapa Village as one of the areas designated as underdeveloped villages [1], makes that village that has specifically received attention in the development plan for rural areas through Buleleng Regent Regulation number 146 of 2018 [2]. Sidetapa Village has developed itself as a tourist village since 2018 [3], has consistently improved its quality by increasing the capacity of tourism village management through tourism awareness groups. In addition to the quality of human resources, the development of tourist villages also requires the availability of habitable space for tourists who want to stay overnight. Accommodation is one of the important elements that can be provided by tourism managers [4] to support tourism activities carried out, including in tourist villages. With the availability of lodging facilities, the length of stay of tourists can provide positive benefits for tourist villages, especially economic benefits. By staying overnight, some of the tourist products offered by the village community to tourists, make it possible to buy them because the stay is quite long, compared to only visiting for a few hours.

Sidetapa Village has developed itself as a tourist village for two years, namely since 2018 and has brought tourists, both domestic and foreign, several times. Some tourists who come often need a place to stay. Their motivation to stay overnight is to be able to learn about 
the culture of the local community, which is the Bali Aga community, which still holds ancient traditions and carries them out to this day. However, based on the initial findings, Sidetapa Village which has been developed as a tourist village is not yet in accordance with nationally enforced standards, namely referring to the Attachment to the Regulation of the Minister of Tourism and Creative Economy No. 09 of 2014 concerning tourist lodges [5]. Thus, the preparation of guest rooms is a consideration in the Partner Village Development Program..

\section{LITERATURE REVIEW}

Trust as a social capital was put forward by Bourdieu as a capital that is able to strengthen one's position in society. Trust, in practice is also very necessary in the development of tourism, especially rural tourism. In this case, as Doxey stated by [6] in his theory of the Index of Irritation caused by Tourism, it is explained that there are five stages of community interaction with tourism, so that people who can not only be understood as individuals and groups, but also as a system will certainly try to maintain balance of the system against the various changes that touch him. The village as a social system, in Talcott Parsons' view of structural functionalism, stipulates four functional requirements in a system, namely: (1) each system must adapt to the environment; 2) each system must have a means to mobilize resources in order to achieve goals and thereby achieve gratification; 3) each system must maintain the internal coordination of the parts and establish ways that correspond to deviations or must maintain their unity; 4) every system must be able to maintain itself as much as possible in a balanced state [7]. Understanding the system, then in the process of community adaptation to tourism development in line with Doxey's view, which can experience five stages depending on the adaptability of the community.

Rural tourism as a form of integration between the components of tourism which is presented in a structure of community life that is integrated with applicable procedures and traditions, in its development requires special handling. In its application, rural tourism is synonymous with community empowerment, so active community participation is needed. Understanding the heterogeneity of the potential, capital and interests of the community, it is necessary to take a good approach so that the community is willing to be involved in the development of tourism, and make a positive contribution to themselves, their environment and their area. In practice, social capital in the form of norms, social networks and social trust can encourage collective action to achieve common goals [8], therefore it is necessary to emphasize social capital in tourism development. As observations have been made such as in Ubud [9], in Padangtegal [10], it was found that social capital, namely public trust in the parties involved in tourism development in the area, is very important to be able to move community to support tourism development.

As [6] found about the irritation index, in practice, tourism developers must understand the complexities that exist in the communities that are the targets or targets of tourism development. Thus, the irritation index as described by [6] cannot be ruled out in the practice of rural tourism development. In this case, the community has social resilience which is the ability of the community to defend themselves and recover from the pressures that occur as a result of social, environmental, economic and political changes [11]. Social resilience is an approach that moves people to create resilient conditions in the face of various pressures [12], with the hope that the needs or interests of each individual experiencing tension will consistently comply with the requirements of the overall system in order to maintain balance and stability social order.

In practice, social resilience shows the ability of social institutions that exist in society that function to maintain their basic functions and seek various solutions to problems. Therefore, in tourism development, apart from understanding the irritation index (Doxey) concept, the stages of tourism development proposed by Butler must also be considered. As Butler's idea in [13], there are six stages of tourism development in an area, namely (exploration, involvement, development, consolidation, stagnation, rejuvenation/decline). Reference [14] who understands the shortcomings in the concept of stages of tourism development, then adds an explanation of the reasons for development, changes, limitations, and disturbances that occur in developed tourist areas. The eight factors that must be considered in tourism development are dynamic, process, tourism capacity and capacity, initiative factor, management, long-term perspective, spatial component, universal application [13]. Of these eight factors, the characteristics of the area that will be built into a tourism area need to be considered and scrutinized properly by the parties involved in tourism development, because this can be a model or type of tourism that will be built so that the tourism developed can be sustainable.

Villages consisting of various natural resources, cultural resources and human resources that have not been managed properly and optimally require the involvement of community leaders and their capital to be able to manage all these resources. Public trust in the character who has a commitment to build his village as a tourist destination will be able to have implications for the construction of the village based on collective awareness. As Durkheim views the importance of society-structure, interaction and social institutions in understanding human thought and behaviour, where he asserts that human needs will always be bound in one community [15]. Society in Durkheim's idea is as a moral order in the form of an ideal reality of normative demands 
contained in the consciousness of the individual, and in a certain way outside the individual [16]. In this case, society is also seen by Durkheim as the most potential place for the gathering of shared life between humans as society develops [17]. Two important concepts in Durkheim's ideas related to explaining social facts are collective consciousness and collective representation. Collective consciousness is a normative consensus that includes belief in religion or belief in other things that support it. Meanwhile, collective images are symbols that are interpreted the same by every individual in a group, which allows them to act the same as members of that group.

The collective picture as the content of collective consciousness, also shows the way members in the group see themselves in relation to the objects that affect them. Collective awareness that has been formed in the community, and shaped by the role of community leaders is able to give birth to a public awareness to support all tourism development activities. This awareness also gives birth to a community attitude that has a sense of responsibility for all village development programs in the form of their responsive actions in each program. Responsiveness shown by their persistence in utilizing and managing the assistance provided to generate income for tourism-aware groups, it can be understood that in the community a form of community loyalty has been created, known as OCB (organizational citizenship behaviour). As stated by [18] and [19], it is explained that OCB is a form of personality of a person who shows a cooperative, helpful, caring attitude, as a form of reciprocation or response to the actions of an organization he receives, where he is part of the organization. It seeks to increase the effectiveness of the organization's functioning actively.

OCB is also known as extra-role behaviour, i.e. performance outside the job requirements of the duties and responsibilities. In this case, there are seven categories of attitudes that are embodied in OCB, namely (1) helpful behaviour, (2) sportsmanship, (3) organizational loyalty, (4) organizational compliance. (5) individual initiative, (6) civic virtue, (7) selfdevelopment. The seven attitudes and behaviours that are a reflection of OCB are very much needed in the development of sustainable tourism, especially at the rural level. The seven attitudes and behaviours that are a reflection of OCB are very much needed in the development of sustainable tourism, especially at the rural level. As stated by [20] regarding leader member exchange, leader member exchange which is one of the strong antecedents of OCB, OCB is strongly influenced by the quality of the relationship that occurs between superiors and workers [21], in this case community leaders with the community itself, which of course is created and established on the basis of trust. At this stage of a supportive situation like this, the resources available in the community can be managed properly, tourists can be well received, and cooperative relationships with parties related to tourism development and development can run well.

\section{METHOD}

The implementation of partner village assistance program activities in Sidetapa Village, Buleleng Regency, Bali has been carried out since 2020. In this program, the community service team provides assistance in preparing habitable rooms for tourists. There are two unused rooms, assisted by the repair process and provided with supporting equipment, so that these rooms can be rented by visiting tourists. The preparation of the room refers to the Regulation of the Minister of Tourism and Creative Economy No. 09 of 2014 concerning tourist lodges [5] which provide standards that must be prepared in a room intended for tourists staying in tourist villages.

The process of preparing guest rooms begins with a discussion of the companion team with the tourism awareness group. Further considerations are made to choose a location where assistance will be provided for the preparation of guest rooms. Then make various necessary repairs and prepare supporting equipment. During the repair process, the companion team provided assistance with building materials, and the work was carried out by the local community, as a form of cooperation between the partner community and academics. The escort team also provides assistance with room equipment, so that rooms can be prepared according to the standards referred to. After all was well prepared, the rooms were ready, well managed by the My Darling Village Sidepata tourism conscious group.

\section{RESULTS \& DISCUSSION}

\subsection{Discussion on Preparing Plans for Preparing Guest Rooms for Tourists in Sidetapa Village, Buleleng, Bali}

Sidetapa Village, which has developed itself as a tourist village, has several times brought in tourists, both domestic and foreign. Some tourists who come often need a place to stay. Their motivation to stay overnight is to be able to learn about the culture of the local community, which is the Bali Aga community, which still holds ancient traditions and carries them out to this day. Thus the availability of lodging [22], is an important tourist need to support their tour activities.

Understanding the needs of tourists, tourism actors in Sidetapa Village try to note things that are important to be prepared by the village in supporting the development of tourist villages. The head of the tourism awareness group, Putu Sinar Jaya (41 years) and Komang Rena (31 years), explained that tourists who visit have difficulty in housing, because there are not yet available rooms that 
are suitable for habitation. Due to the unavailability of lodging, tourists stay in the Lovina area, which of course does not provide direct economic benefits [23] for the people in Sidetapa Village. The presence of tourists staying in Sidetapa Village will have an impact on receiving some income from room rent and food consumption. Likewise, the length of stay of more than one day allows them to carry out tourist activities, such as providing foreign language training to the surrounding community, and buying local products as souvenirs.

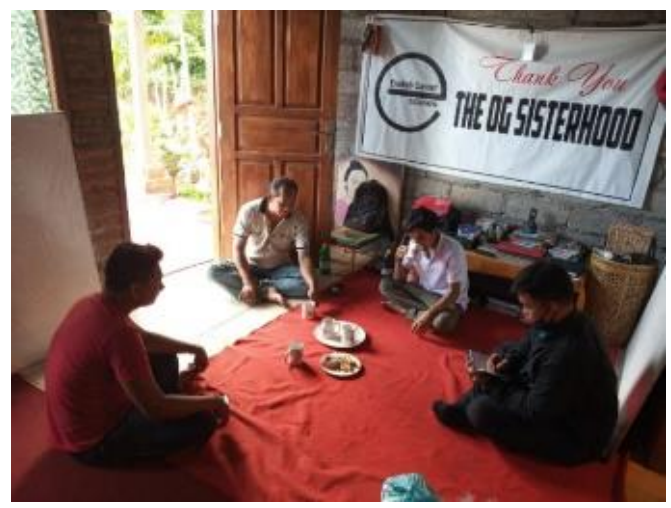

Figure 1 Discussion on the Implementation of the Preparation of Guest Rooms in Sidetapa Village.

Preparing Sidetapa Village as a tourist village requires an active role from the local community, especially their openness in accepting outsiders, both as tourists and parties who want to provide assistance programs. Reference [3], there are three factors that tourist villages can develop themselves as tourist destinations properly, namely the availability of humans who are able to manage and develop tourism concepts well, have advantages that can be used as tourism development concepts that make themselves different from tourist villages others, as well as strong support from all elements of the community in the village itself.

Understanding the importance of community participation, in the early stages of implementing the village tourism assistance program, discussions on the preparation of program planning were carried out intensively (see Figure 1), with the aim of being able to build understanding and agreement between the parties involved. Tourism development at the village level does require an active role from the village community itself, with the aim of developing a village as a tourist destination to be able to benefit all parties involved in it. Reference [24] in his research explains that the tourism awareness group as a social institution formed from below and supported by the government can have implications for the seriousness of the community in managing the tourism potential of their village.

A tourism awareness group [25] is a self-subsistent and self-help group that grows from, by and for the community that aims to increase the development of tourism activities in the region and support national tourism development. Tourism awareness groups as community organizations that function to manage tourism potential in their villages, of course need the assistance of the government and academics in their formation and management. As reference [26] explains the importance of the role of government, academics, and NGOs in providing guidance, training, mentoring, as well as material donations that are beneficial for the development and development of tourism at the village level.

Discussions between parties involved in the mentoring program are important, considering the need for sustainability programs that can provide benefits, especially for the community itself. Borrowing the idea of communicative action developed by Habermas is the existence of a democratic process [27], it is hoped that all parties can present their arguments without pressure from any party. In this context, there are four validity claims put forward by Habermas, namely clarity, truth, accuracy, and sincerity, where in its implementation it is hoped that there will be an ideal speaking situation, namely that each party is given freedom of opinion while still carrying the prevailing values and norms. Through communicative action, it is understood that every social life requires a coordination to solve various problems or demands that disagreements about what is good to do, namely morality, need to be resolved in fair and wise ways [28], so that every individual involved, can appreciate and respect each other.

\subsection{Preparation of a Tourist Stay at the English Corner which is as a Centre for Learning English Languages for the Local Community}

The availability of accommodation in a tourist destination [29] is one of the important requirements that must be considered in tourism development, including tourist villages. Sidetapa Village as a tourist village that has a unique culture and natural beauty, has been visited by both domestic and foreign tourists. One of the activities for this partner village assistance program is to prepare a guest space for tourists. The guest space is prepared in accordance with the Regulation of the Minister of Tourism and Creative Economy of the Republic of Indonesia Number 9 of 2014 concerning the Standards of Homestay. As stated in the regulation, it is explained that the tourist lodge business is the provision of accommodation in the form of residential buildings that are inhabited by the owner and partly used for rent by providing opportunities for tourists to interact in the daily life of the owner.

The preparation of the first habitable space was carried out at the foreign language learning centre, namely the English Corner which was managed by the My Darling tourism awareness group. The English corner is a learning place for people in Sidetapa Village who want to get free English lessons. English Corner is one of 
the destinations for tourists visiting Sidetapa Village. In this case, most of the tourists who visit Sidetapa Village, besides having the aim of getting to know the local culture, are also to actualize themselves as volunteer tourists. Volunteer tourism [30] is a contemporary tourism activity in which a tourist offers their services to make some good changes in society, in which they are actively involved in its implementation.
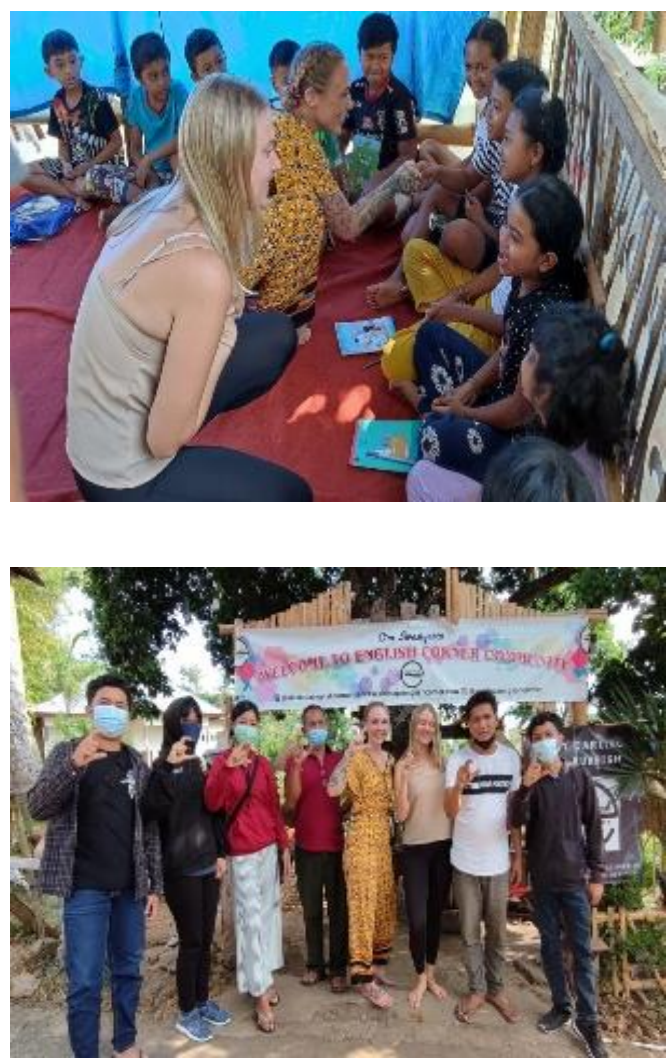

Figure 2 Volunteer Tourism in Sidetapa Village.

Sidetapa Village is often visited by tourists who have the motivation to do various forms of kindness to the local community, as long as they travel. The presence of tourists with this motivation provides social, cultural and environmental assistance for the local community. Komang Rena (31 years old), explained that tourists with volunteer motivation have a relatively long stay (see Figure 2). The length of stay of tourists [31], [32] contributes to the income of the area visited, which is generated from the rental of lodging, consumption of food and other tourism products. However, unavailability of rooms that can be rented out, income from lodging cannot be generated. Therefore, in the partner village assistance program, improvements are made to the existing room so that they become habitable spaces for tourists who visit and want to stay in Sidetapa Village.



Figure 3 Repairing Guest Room

The room in the foreign language learning centre known as the English Corner are improved by collaboration between community service team and tourism awareness groups. On that occasion, the academic team provided material assistance for the repair of the room and training in preparing ready-to-use rooms. The Community Service Program is a mandatory program for academics. As stated in the XII edition of the research and community service guidebook, it is stated that universities are obliged to carry out research and community service in accordance with the mandate of Law Number 20 of 2003 concerning the National Education System in Article 20. Understanding community service programs as a matter of mandatory that must be carried out by academics, then every lecturer also makes activities in the form of training, coaching and mentoring to the community, both those concerning the social, economic, cultural, political, environmental, and technological fields, which aim to improve the quality of the target partners who receive a service program.

The provision of guest rooms requires the active role of the community in Sidetapa Village, especially the My Darling tourism awareness group. The non-directive (participatory) approach is based on the assumption that people know what they really need and what is good for them [33]. Understanding these conditions, in the assistance activities of partner villages in Sidetapa Village (see Figure 3), tourism awareness groups play a role as the main actor in changes in the village. In this case, the My Darling tourism awareness group is given the opportunity to make analysis and make decisions that are useful for their group and the community in Sidetapa Village to achieve their goals. 


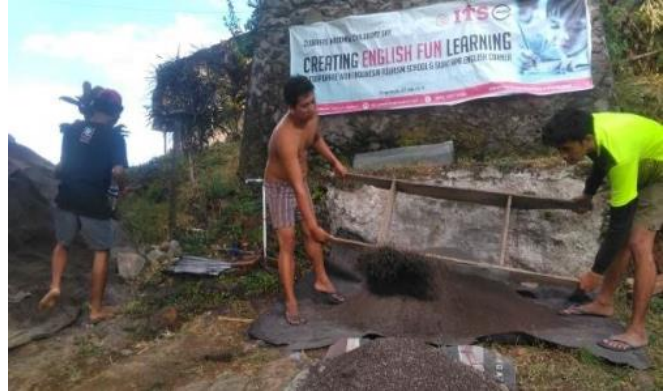

Figure 4 My Darling Tourism Awareness Group Working Together to Prepare Habitable Spaces for Tourists

Understanding the benefits that will be received, during the process of repairing habitable spaces and preparing toilets, program partners, namely the My Darling tourism awareness group, worked together to make improvements. As a village that was initially very closed, it was difficult to accept changes, along with their needs that could be met through collaboration with outsiders, they also opened themselves up to partner with the companion team. Sidetapa Village as a social system, has made various changes [7], to achieve life stability by adapting to tourism development. Likewise, they are willing to adopt standards for the provision of liveable space in accordance with the standards in the Regulation of the Minister of Tourism and Creative Economy No.09 of 2014.



Figure 5 Room and Toilet Repair Results

The availability of clean rooms and toilets is one of the requirements for developing a tourist village. Clean tourist facilities [34], [35], are important things that must be considered by tourism service providers. This is in accordance with the principles of Sapta Pesona. Sapta Pesona [34] is very important to be applied to tourist villages, with the aim that tourism actors, especially tourism aware groups are able to develop a village into a tourist destination that gives the impression of being safe and comfortable for tourists. The learning centre (English corner) of Sidetapa Village is regularly visited by tourists, especially foreign tourists. Most of them choose to stay for two to three days, especially those who are motivated to learn the culture of the village and provide free foreign language learning, especially for school children. The needs of tourists during their visit are not only a decent place to live, but also clean and good eating and drinking facilities for consumption. Tourists with this motivation really like to enjoy food and drinks with a rural atmosphere. Therefore, the provision of a place to eat with a rural atmosphere can be prepared by tourism actors in Sidetapa Village. The practice of providing a place to eat in the village [36] of course must pay attention to cleanliness, both eating and drinking utensils, as well as the environment.

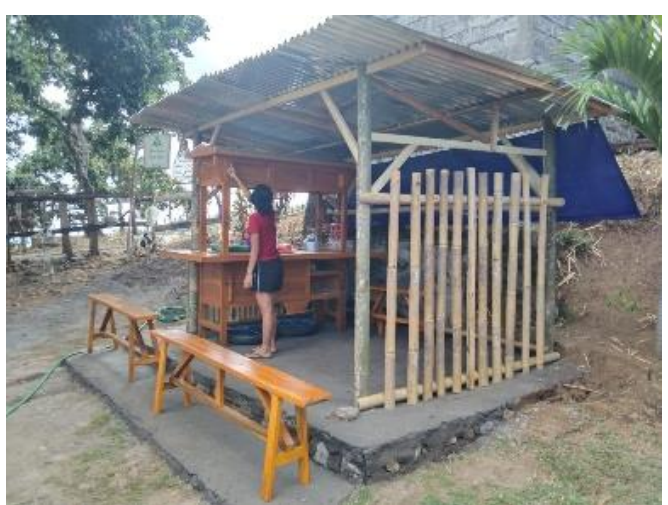

Figure 6 Carts and Equipment to be used as a place to sell food by Pokdarwis

Understanding the needs of tourists visiting Sidetapa Village for the availability of clean places to eat in the village, in this partner village assistance program, the team collaborates with partners to prepare these facilities (Figure 6). It is hoped that with the availability of liveable space, adequate toilets and clean eating places, the tourism conscious group will be able to develop themselves into village tourism entrepreneurs who can contribute positively to Sidetapa Village in terms of social, cultural, environmental and economic aspects.

\subsection{Preparation of Guest rooms at the Bamboo Centre which is as a Place for Empowering Women Weavers in Sidetapa Village}

The partner village assistance program carried out by a team of academics, namely lecturers and students of Ganesha Education University, has been carried out for two years. During the mentoring process, community trust was built with the aim of making the program sustainable in the management of the local community, namely by the My Darling tourism awareness group and community leaders in Sidetapa Village. Trust is of course an important social capital to be built in service programs. As reference [37]'s notion of the value of a belief can only function as long as at the same time it also produces these products through practices. In practice, social capital in the form of trust is a capital worth fighting for survival, existence of life, as well as for obtaining economic benefits. Furthermore, reference [38] also pays special attention to the element of trust, as a capital that should be taken into account in establishing a collaboration, both individually and in groups. Trust [38] as social capital serves as a network to form closer relationships that can create networks and ties, that is, 
they often shape the quality of life. Thus, trust as one of the social capital is very important in fostering a cooperative relationship. In practice, trust as an important capital in establishing a relationship and cooperation is also carried out by several parties in tourism development.

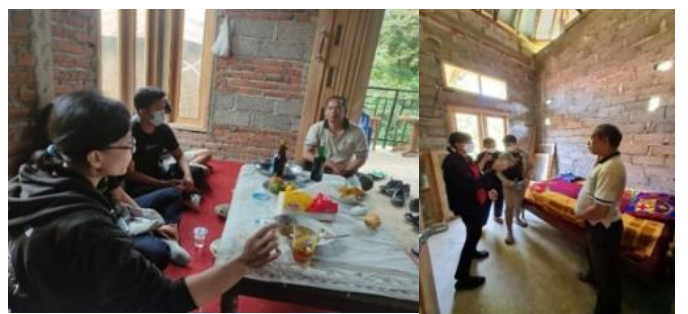

Figure 7 Discussion on the preparation of habitable rooms at the Bamboo Craft Center of Sidetapa Village

Discussion is an important thing to do by involving all parties who will be invited to implement the action plan. As applied to the preparation of rooms in English Corner in 2020, further discussions also held on the implementation of the program in 2021 (Figure 7). To build a sense of togetherness, Habermas' communicative actions [39] are always used as an initial step before the implementation of the mentoring program. Communicative action is considered a very important option to create a good understanding between the parties involved in the program, namely academics and partners, namely the Sidetapa Village community. The building of trust gave birth to the formation of collective awareness, which in turn formed an awareness of 4R (Respect, Responsive, Response, and Responsible) in Sidetapa Village. The community is able to accept the purpose of implementing the partner village assistance program well as evidenced by the community's readiness to work together to prepare guest room facilities and the presence of village assistance in the form of building toilets that complement tourist facilities at the centre of bamboo craft.

In Figure 8, it can be seen that the community gotong royong prepared a room that would be managed by the My Darling tourism awareness group, Sidetapa Village. This condition shows the 4R attitude, namely (1) Respect, is a condition of the community that respects every activity that occurs in their environment, including respecting and appreciating tourists and other tourism actors who come to their area; (2) Responsive, is a condition of the people who are willing to listen well and politely to the words and questions raised by outsiders who have data in their area, especially by tourists and other tourism actors; (3) Response, is a condition of the community that is able to provide good responses to the presence of outsiders including tourists and other tourism actors, and is able to provide good and correct answers to questions given by these outsiders, especially those related to tourism; and (4) Responsible, is a condition of the community willing to participate actively to be responsible for everything that happens in their area, especially those related to tourism development and development. At this stage, the community has been able to show themselves as individuals who are ready to be part of the tourism development carried out in their area, as evidenced by their ability to know their duties properly and correctly, and have the same vision, mission and goals, namely building sustainable rural tourism. The implementation of the $4 \mathrm{Rs}$ as described above, if the community stage is already at a high responsible stage, then it can be understood that in the community a form of community loyalty has been created [18], [19].

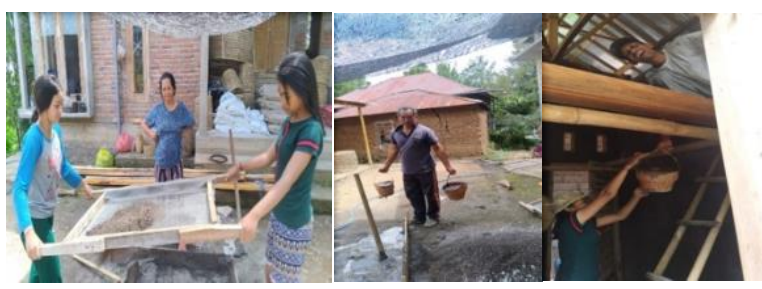

Figure 8 Prepares Guest Rooms by Tourist Awareness Group Sidetapa Village



Figure 9 Practice Preparing the Guest Room

The collaboration between the companion team and partners resulted in a room that was ready to be managed by a tourism awareness group in Sidetapa Village with the aim of getting income from the sale of rooms (Figure 9). The availability of rooms that can be rented out to guests at the bamboo craft center is expected not only to provide income through the sale of rooms, but also to have a social and cultural impact, especially for women craftsmen in Sidetapa Village. In this bamboo center, some women in Sidetapa Village work as weavers of various types of bamboo handicrafts (Figure 10). This bamboo craft center is one of the places frequented by both local and foreign tourists.

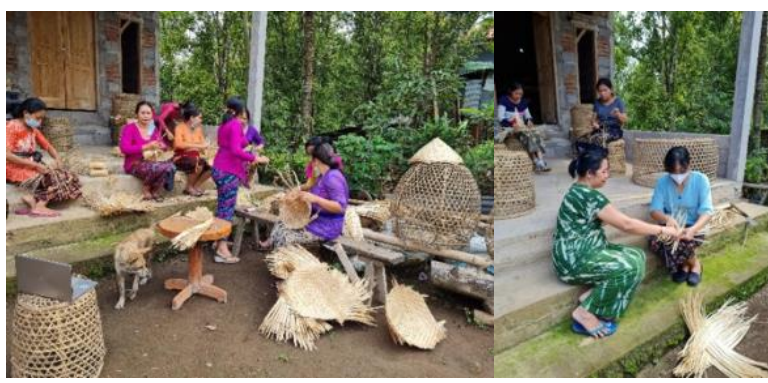

Figure 10 Women Weavers at the Bamboo Craft Centre of Sidetapa Village 
The availability of a place to stay for tourists at the bamboo craft centre in Sidetapa Village is expected to be able to provide benefits for the owner of the craft centre, bamboo craftsmen and tourism-aware groups in the village. Reference [35] argue that village tourism is one solution to improve the village economy, one of which is the availability of homestays that play a role in community empowerment. The availability of guest rooms whose preparation standards refer to the Regulation of the Minister of Tourism and Creative Economy of the Republic of Indonesia Number 9 of 2014 concerning Business Standards for Pondok Wisata, is expected to be able to provide economic, social, cultural and environmental benefits in a sustainable manner for Sidetapa Village which has committed to trying to develop itself as a one of the cultural tourism villages in Buleleng Regency.

\section{CONCLUSION}

The village as a social system will make changes and adaptations along with the times and the increasing demands for meeting the needs of the community. One of the things that the village does is accept the changes that occur and the development of various aspects of life. With these changes, the community is also required to be able to adapt so as to achieve a balance of life. Likewise, what happened to Sidetapa Village which opened itself to change, and accepted the change in the form of developing itself as a tourist village. Tourism is also understood as a solution in increasing the value of local products in the village. Understanding this, Sidetapa Village has been diligently developing itself as a tourist village since 2018 until now, although the impact of the COVID-19 pandemic has been felt, namely the decline in tourist visits. This does not make the people of Sidetapa Village discourage themselves from developing themselves as a tourist village, especially the My Darling tourism awareness group which has been confirmed by the village and the service as a group of village-level tourism activists.

Through the partner village assistance program, the people of Sidetapa Village, namely the leaders, tourism awareness groups and crafter groups collaborate in preparing tourist facilities in the form of habitable rooms, toilets and clean eating places for tourists. The program, which has been implemented for two years, has resulted in the availability of two guest rooms that have been managed by a tourism awareness group in Sidetapa Village. The availability of adequate lodging in foreign language learning centres, in addition to providing economic benefits, also provides cultural benefits, namely the existence of free native speaker teachers for students in Sidetapa Village. Course fees paid with plastic waste also have an impact on the cleanliness of the village environment. Meanwhile, the availability of lodging at craft centres, in addition to having an impact on obtaining economic benefits, also provides opportunities for weaver mothers to interact and learn foreign languages with tourists.

This paper is limited to the preparation of guest rooms and supporting facilities that can make the sidetapa village the choice of tourists who have cultural motivation and volunteers. Henceforth, a study on the analysis of guest room needs can be carried out by adjusting the readiness of the village and the number of tourist visits.

\section{REFERENCES}

[1] N. N. Di. Andiani, "Pengembangan Wisata Tematik di Kawasan Perdesaan Bali Aga Kecamatan Banjar, Kabupaten Buleleng - Bali,” Universitas Udayana, 2021.

[2] Pemerintah Daerah Kabupaten Buleleng, Peraturan Bupati Buleleng Nomor 146 Tahun 2018. Indonesia, 2018.

[3] N. M. A. Widiastini, M. A. Prayudi, and P. I. Rahmawati, "Preparing Sidatapa Village as a Bali Aga Tourist Attraction in Buleleng Regency," in Proceedings of the 5th International Conference on Tourism, Economics, Accounting, Management and Social Science (TEAMS 2020), 2020, vol. 158, no. Teams, pp. 305-311, doi: 10.2991/aebmr.k.201212.043.

[4] I. Setyanto and E. Pangestuti, "Pengaruh Komponen Destinasi Wisata (4a) Terhadap Kepuasan Pengunjung Pantai Gemah Tulungagung," J. Adm. Bisnis, vol. 72, no. 1, pp. 157-167, 2019.

[5] Kementerian Pariwisata dan Ekonomi Kreatif Republik Indonesia, Lampiran Peraturan Menteri Pariwisata dan Ekonomi Kreatif Nomor 09 Tahun 2014 tentang Usaha Pondok Wisata. Indonesia, 2014.

[6] G. Doxey, "A Causation Theory of Visitor: Resident Irritant Methodology and Research Inference," 1975.

[7] I. B. Wirawan, Teori-teori Sosial dalam Tiga Paradigma (Fakta Sosial, Definisi Sosial, dan Perilaku Sosial). Jakarta: Prenada Media Grup, 2012.

[8] M. K. Johnson and S. J. Sherman, "Constructing and Reconstructing the Past and the Future in the Present," in Handbook of motivation and cognition: Foundations of social behavior, E. T. Higgins and R. M. Sorrentino, Eds. The Guilford Press, 1990.

[9] N. M. A. Widiastini, "Pemanfaatan Puri Ubud Sebagai Objek Wisata Serta Implikasinya Terhadap Desa-Desa Di Kawasan Pariwisata 
Ubud, Gianyar, Bali,” 2008.

[10] I. R. Ningrum, “Analisis Peran Modal Sosial terhadap Pemberdayaan Masyarakat dalam Melestarikan Kebudayaan dan Pengembangan Sektor Pariwisata (di Desa Padang Tegal, Kecamatan Ubud, Kabupaten Gianyar, Bali)," J. Ilm. Ilmu Ekon. dan Bisnis Univ. Brawijaya Malang, vol. 2, no. 2, pp. 1-14, 2014.

[11] K. Kartono, Patologi Sosial. Jakarta: Raja Grafindo Persada, 2005.

[12] D. Bahransyaf, Model Jaminan Sosial Berbasis Komunitas Lokal dalam Penguatan Ketahanan Sosial Masyarakat. Jakarta: Pusat Pengembangan Ketahanan Sosial Masyarakat. Departemen Sosial RI, 2005.

[13] Z. Kruczek, M. Kruczek, and A. R. Szromek, "Possibilities of using the tourism area life cycle model to understand and provide sustainable solution for tourism development in the antarctic region," Sustain., vol. 10, no. 1, pp. 1-16, 2018, doi: 10.3390/su10010089.

[14] R. W. Butler, "The Concept of a Tourist Area Cycle of Evolution: Implications for Management of Resources," Can. Geogr., vol. 24 , no. 1 , pp. 5-12, 2008, doi: $10.1111 /$ j.15410064.1980.tb00970.x.

[15] D. P. Johnson, Teori Sosiologi Klasik dan Modern. Jakarta: PT. Gramedia Pustaka Utama, 1994.

[16] S. B. Campbell, "Hard-to-Manage Preschool Boys: Externalizing Behavior, Social Competence, and Family Context at Two-Year Followup," J. Abnorm. Child Psychol., vol. 22, pp. 147-166, 1994.

[17] D. A. I. Muhni, Moral \& religi menurut Emile Durkheim \& Henri Bergson. Yogyakarta: KANISIUS, 1994.

[18] F. Luthans, Perilaku Organisasi, 10th ed. Yogyakarta: Andi Offset, 2006.

[19] T. M. Nielsen, D. G. Bachrach, E. Sundstrom, and T. R. Halfhill, "Utility of OCB: Organizational Citizenship Behavior and Group Performance in a Resource Allocation Framework," J. Manage., vol. 38, no. 2, pp. 668694, 2012, doi: 10.1177/0149206309356326.

[20] D. W. Organ, P. M. Podsakoff, and S. B. MacKenzie, Organizational Citizenship Behavior: Its Nature, Antecedents, and Consequences. California: SAGE Publication Inc., 2006.

[21] R. Loi, X. Lin, and A. J. M. Tan, "Powered to Craft? The Roles of Flexibility and Perceived Organizational Support," J. Bus. Res., vol. 104, pp. 2019, 61-68, doi: https://doi.org/10.1016/j.jbusres.2019.07.002.

[22] A. S. Pramudita, "Digital Media Preferences of Hostel Backpacker Consumer in Bandung Using Recommendation Score," J. Compet., vol. 15, no. 1, pp. 26-33, 2020, doi: https://doi.org/10.36618/competitive.v15i1.673.

[23] H. Hermawan, "Dampak Pengembangan Desa Wisata Nglanggeran terhadap Ekonomi Masyarakat Lokal," vol. III, no. 2, pp. 105-117, 2017, doi: 10.31219/osf.io/xhkwv.

[24] F. Rahim, Pedoman Kelompok Sadar Wisata. Jakarta: Direktur Jenderal Pengembangan Destinasi Pariwisata Kementerian Pariwisata dan Ekonomi Kreatif, 2012.

[25] C. Putra, "Pengelolaan Alokasi Dana Desa Dalam Pemberdayaan Masyarakat Desa (Studi Pada Desa Wonorejo Kecamatan Singosari Kabupaten Malang))," J. Adm. Publik Mhs. Univ. Brawijaya, 2013.

[26] M. H. U. Dewi, C. Fandeli, and M. Baiquni, "Pengembangan Desa Wisata Berbasis Partisipasi Masyarakat Lokal Di Desa Wisata Jatiluwih Tabanan, Bali," J. Kawistara, vol. 3, no. 2, pp. 129-139, 2013, doi: 10.22146/kawistara.3976.

[27] C. Barker, Cultural Studies: Teori dan Praktek. Yogyakarta: Bentang, 2005.

[28] N. C. Crawford, "Jurgen Habermas,"” in Teoriteori Kritis Menantang Pandangan Utama Studi Politik Internasional, J. Edkins, N. V. Williams, and T. W. Utomo, Eds. Yogyakarta: Baca, 2020.

[29] R. Kurniansah and M. S. Hali, "Ketersediaan Akomodasi Pariwisata Dalam Mendukung Pariwisata Perkotaan (Urban Tourism) Sebagai Daya Tarik Wisata Kota Mataram Provinsi Nusa Tenggara Barat,” J. Bina Wakya, vol. 1, no. 1, pp. 39-44, 2018, [Online]. Available: http://ejurnal.binawakya.or.id/index.php/JBW.

[30] M. Callanan and S. Thomas, "Volunteer Tourism: Deconstructing Volunteer Activities within a Dynamic Environment," in Niche Tourism: Contemporary Issues, Trends and Cases, M. Novelli, Ed. Oxford: ButterworthHeinemann, 2005.

[31] I. N. Wijaya, "Analisis Jumlah Wisatawan Mancanegara, Lama Tinggal, dan Kurs Dollar Amerika Terhadap Penerimaan Produk Domestik Bruto Kabupaten Badung," Soshum J. Sos. dan Hum., vol. 6, no. 2, pp. 188-200, 2016.

[32] I. G. Y. Suastika and I. N. M. Yasa, "Pengaruh Jumlah Kunjungan Wisatawan, Lama Tinggal Wisatawan dan Tingkat Hunian Hotel Terhadap Pendapatan Asli Daerah dan Kesejahteraan Masyarakat Pada Kabupaten/Kota di Provinsi 
Bali,” E - J. Ekon. Pembang. Univ. Udayana, vol. 6, no. 7, pp. 1157-1394, 2017.

[33] I. R. Adi, Intervensi Komunitas dan Pengembangan Masyarakat Sebagai Upaya Pemberdayaan Masyarakat. Jakarta: PT Raja Grafindo Persada, 2012.

[34] L. Hendriyati, "Upaya Masyarakat di Desa Wisata Penglipuran dalam Menjalankan Sapta Pesona," J. Tour. Econ., vol. 3, no. 1, pp. 49-57, 2020, doi: https://doi.org/10.36594/jtec.v3i1.54.

[35] H. Widyaningsih, "Pengembangan Pengelolaan Homestay Dalam Mendukung Desa Wisata Diro Sendangmulyo, Kecamatan Minggir, Kabupaten Sleman," Khasanah Ilmu J. Pariwisata dan Budaya, vol. 11, no. 1, pp. 9-15, 2020, doi: 10.31294/khi.v11i1.782.

[36] Priyanto and D. Safitri, "Pengembangan Potensi Desa Wisata Berbasis Budaya Tinjauan terhadap Desa Wisata di Jawa Tengah," J. Vokasi Indones., vol. 4, no. 1, pp. 76-84, 2016.

[37] P. Bourdieu, Arena Produksi Kultural Sebuah Kajian Sosiologi Budaya. Yogyakarta: Kreasi Wacana, 2010.

[38] K. Plummer, Sosiologi: The Basics. Jakarta: Raja Grafindo Persada, 2011.

[39] F. Magnis-Suseno, Pemikiran Karl Marx: Dari Sosialisme Utopis ke Perselisihan Revisionisme. Jakarta: PT Gramedia Pustaka Utama, 2001. 